\title{
Perturbation of seafloor bacterial community structure by drilling waste discharge
}

\author{
Tan Thi Nguyen ${ }^{\mathrm{a}}$, Sabine K.J. Cochrane ${ }^{\mathrm{b}}$, Bjarne Landfald ${ }^{\mathrm{a}, *}$ \\ a Norwegian College of Fishery Science, Faculty of Biosciences, Fisheries and Economics, UiT The Arctic University of Norway, Breivika, N-9037 Troms $\phi$, Norway \\ b Akvaplan-niva AS, Polar Environmental Center, 9296 Troms $\phi$, Norway
}

\section{A R T I C LE IN F O}

Keywords:

Drill cutting

Seafloor

Bioindicator

Microbiota

Barents Sea

\begin{abstract}
A B S T R A C T
Offshore drilling operations result in the generation of drill cuttings and localized smothering of the benthic habitats. This study explores bacterial community changes in the in the upper layers of the seafloor resulting from an exploratory drilling operation at $1400 \mathrm{~m}$ water depth on the Barents Sea continental slope. Significant restructurings of the sediment microbiota were restricted to the sampling sites notably affected by the drilling waste discharge, i.e. at $30 \mathrm{~m}$ and $50 \mathrm{~m}$ distances from the drilling location, and to the upper $2 \mathrm{~cm}$ of the seafloor. Three bacterial groups, the orders Clostridiales and Desulfuromonadales and the class Mollicutes, were almost exclusively confined to the upper two centimeters at $30 \mathrm{~m}$ distance, thereby corroborating an observed increase in anaerobicity inflicted by the drilling waste deposition. The potential of these phylogenetic groups as microbial bioindicators of the spatial extent and persistence of drilling waste discharge should be further explored.
\end{abstract}

\section{Introduction}

Drilling for oil and gas generates quantities of waste that originate from the release of drilling muds and rock cuttings, collectively referred to as drill cuttings, and often also excess cement or other materials used. The amount of waste depends on the drilling depth, and the environmental impact of this discharge depends on its quantity and composition, local oceanographic conditions and the discharge strategy adopted. Since the early 1990s, the Norwegian environmental regulatory authorities have prohibited the discharge of drill cuttings using oil-based drilling muds, such that either water based muds or closed systems are used. The oil content of released drill cuttings with accompanying drilling mud residuals should not exceed $1 \%$. Materials exceeding this threshold level are slurrified and reinjected or transported onshore for cleanup. Hence, the drilling waste currently deposited on the seafloor in the vicinity of the drilling sites largely comprises rock debris, mineral weight material (e.g. barite, ilmenite) and smaller amounts of residual, water-soluble chemical components. As baseline levels of barium (Ba) in sediments are generally low, the barite-derived Ba is commonly used as a sensitive tracer of dispersal and persistence of discharges from drilling operations (Kennicutt et al., 1983; Phillips et al., 1998; Ellis et al., 2012).

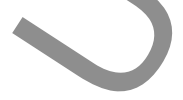

\footnotetext{
* Corresponding author.

Email address: bjarne.landfald@uit.no (B. Landfald)
}

https://doi.org/10.1016/j.marpolbul.2017.10.039 Received 28 June 2017; Accepted 18 October 2017 Available online xxx
$0025-326 /$ (c) 2017.
Although the environmental impacts of the discharges of waterased drill cuttings are considerably less than those of the previously-used oil-based varieties (Bakke et al., 2013), mesocosm and field experiments have demonstrated effects on the benthic macrofauna (Schaanning et al., 2008; Trannum et al., 2010). As might be expected, the intensity of these effects is dependent on the thickness of the deposited layer. However, contrary to previous assumptions, oxygen depletion, anticipated to be induced by microbial catabolism of organic components in the drilling fluids, seems to have a stronger negative impact on the benthos than the plain burial effect caused by drill cuttings sedimentation (Trannum et al., 2010). The radius of seriously affected benthic communities coincides rather closely with the visually evident spread of drilling waste and is rarely reported to extend beyond 100-200 m. The affected area is furthermore shown to diminish gradually over time after termination of the drilling operations (Daan et al., 2006; Gates and Jones, 2012; Jones et al., 2012).

Only few studies have been published on the microbiological effects of drilling muds and cuttings deposition, and their focus has largely been on the consequences of using oil-based muds. In a North Sea field study, Sanders and Tibbetts (1987) demonstrated increased hydrocarbon-degrading and sulfate-reducing activity as far out as $500 \mathrm{~m}$ from the center of a drill cuttings pile if aromatics-rich diesel based drilling muds were employed, whereas less toxic aliphatics 
based muds led to less far-reaching effects. Anaerobic degradation of hydrocarbon components in drill cuttings was demonstrated by Artz et al. (2002). A mesocosm study by Dow et al. (1990) showed less distinct and long-lasting, but still significant changes in microbial activity after covering sediment with water based drill cuttings.

A number of factors, both biotic and abiotic, could be expected to influence the microbial community structure in the upper seafloor sediment. These factors include climate, water depth, intensity and character of benthic-pelagic coupling, geo-chemical characteristics of the sediment and level of macrofaunal bioturbation. However, some universal features still characterize upper sediment microbiotas and distinguish them from the overlaying pelagic realm on the one hand and the deep sediment biosphere on the other. The phylogenetic richness is very high both at species and higher taxonomic levels and compares with that of e.g. unperturbed soil communities (Torsvik et al., 1998; Roesch et al., 2007). Gammaproteobacteria and Deltaproteobacteria commonly constitute major taxonomic groups and otherwise rather uncommon taxa like Planctomycetes and Chloroflexi are also amply represented (Bertics and Ziebis, 2009; Orcutt et al., 2011; Zinger et al., 2011; Bienhold et al., 2012; Nguyen and Landfald, 2015).

A well-documented effect of drilling waste discharge is an increased anoxicity in the upper sediment strata. The suggested primary cause of this effect is increased oxygen demand by components in the muds, but reduced $\mathrm{O}_{2}$ diffusion due to fines that settle onto the seabed, as well as reduced bioturbation by burrowing animals, may also contribute to oxygen depletion in the affected sediment (Trannum et al., 2011; Ellis et al., 2012). Furthermore, chemical components in the muds may have selective effects by promoting or inhibiting the growth of specific groups of microorganisms, thereby distorting the pristine phylogetic structure of the sediment communities.

In the present study we explore the character and spatial extent of changes in bacterial community structure following exposure to discharged drilling waste at a recently abandoned drilling location on the south-western continental slope of the Barents Sea. By combining a comprehensive partial 16S rRNA gene based community analysis with analyses of relevant environmental variables, we aimed at elucidating the closeness between community change and variations in direct and indirect influences of drilling waste discharge. Furthermore, using community analyses, we aimed to determine if affected sediments were characterized by specific phylogenetic groups of bacteria which, if so, would have a potential as bioindicator of the spatial and temporal extent of this type of seafloor perturbation.

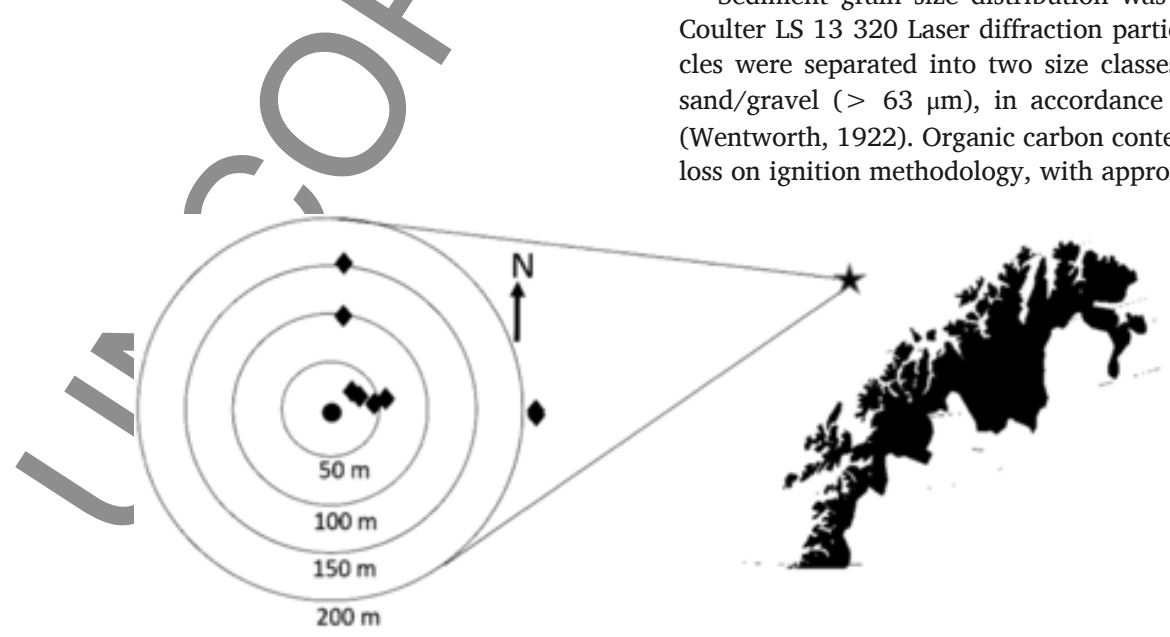

Fig. 1. Geographical position of the drilling site in northern Norway and the corer sampling locations (diamonds) relative to the drilling site in the mid position.

\section{Material and methods}

\subsection{Sampling}

Sediment push corer samples (8 cm i.d., $50 \mathrm{~cm}$ length PVC tubes; Planet Ocean Ltd., UK) were collected by means of a working class remotely operated vehicle (ROV; Magnum Plus, Oceaneering AS) on 1-2 December 2013. The ROV was operated from the sub-sea anchor-handling vessel M/V Njord Viking (Viking Supply Ships, Gothenburg). The sampling was done in the yicinity of an drilling location at close to $1400 \mathrm{~m}$ depth at the Bønna location, situated on the continental slope of the Barents Sea towards the Norwegian Sea (Fig. 1) with Eni Norge as main operator. The site was drilled during the period 14th of July-8th of November 2013, implying that the drilling of the top hole ( $567 \mathrm{~m}$ ) which led to discharge of drilling waste on the seafloor, took place in the first month of this period (Paulsen et al., 2014). The estimated quantity of drilling mud discharged to the seafloor from the top hole of the drilling site was about $1260 \mathrm{~m}^{3}$. Eight corer samples were collected at distances of 28 , $33,43,55,100,155,210$ and $210 \mathrm{~m}$ from the drilling location (Fig. 1). In the following data presentations, the two first-mentioned cores are treated as $30 \mathrm{~m}$ duplicates, the next two as $50 \mathrm{~m}$ duplicates and the last two as $210 \mathrm{~m}$ duplicates.

On board, oxygen concentrations were recorded at 0.5, 1.5 and $3.5 \mathrm{~cm}$ from the core surface, corresponding to the mid-depths of the three uppermost core sections (see below), by use of a $\phi 1.1 \mathrm{~mm}$ needie sensor coupled to an amplifier unit (Unisense AS, Aarhus, Denmark). Aerated seawater and $100 \mathrm{mM}$ ascorbate in $100 \mathrm{mM} \mathrm{NaOH}$ were used as saturation and anoxic calibration points, respectively, according to the manufacturer's recommendation. Each core was subsequently sliced into four sections, $0-1,1-2,2-5$ and $5-10 \mathrm{~cm}$ from the surface, mixed to homogeny in sterile plastic bags and frozen immediately at $-25{ }^{\circ} \mathrm{C}$. On arrival to the onshore laboratory facilities, the samples were transferred to $\mathrm{a}-72{ }^{\circ} \mathrm{C}$ freezer for storage. The individual samples were subjected to geochemical and 16S rRNA gene based bacterial community analyses. However, in one of the $30 \mathrm{~m}$ cores, the amount of sediment recovered from the uppermost $1 \mathrm{~cm}$ layer was sufficient only for bacterial community analysis, not for geochemical analyses.

\subsection{Sediment characteristics}

Sediment grain size distribution was determined by a Beckman Coulter LS 13320 Laser diffraction particle size analyzer. The particles were separated into two size classes; clay/silt $(<63 \mu \mathrm{m})$ and and/gravel $(>63 \mu \mathrm{m})$, in accordance with the Wentworth Scale (Wentworth, 1922). Organic carbon content was estimated by weight loss on ignition methodology, with approximately $3 \mathrm{~g}$ starting mater- 
ial, heating at $550{ }^{\circ} \mathrm{C}$ for $12 \mathrm{~h}$ and 0.58 as conversion factor (Wang et al., 2011). The pore water nitrate concentration was determined by azo dye formation after reduction of nitrate to nitrite by cadmium, according to the following protocol: sediment samples $(0.5 \mathrm{ml})$ were spun at $10000 \mathrm{rpm}$ for $10 \mathrm{~min}$ in polyethersulfone centrifugal filters with $30 \mathrm{kD}$ cutoff (VWR prod.no. 516-0231). The filtrate volume was precisely determined and diluted to $0.5 \mathrm{ml}$ with $3 \% \mathrm{NaCl}$, then added $0.5 \mathrm{ml}$ Mixed Acid Reagent (LaMotte Company; prod.no. V-6278). After $2 \mathrm{~min}, 20 \mathrm{mg}$ of Nitrate Reducing Agent (LaMotte Company; prod.no. V-6279) was added followed by tube inversion each second for $1 \mathrm{~min}$. After $10 \mathrm{~min}$, absorbance at $540 \mathrm{~nm}$ was recorded spectrophotometrically (Spekol 2000, Analytik, Jena, Germany) in a $1 \mathrm{~cm}$ light path cuvette. Standard solutions (0-50 $\mu \mathrm{M})$ were made by diluting $\mathrm{KNO}_{3}$ in $3 \% \mathrm{NaCl}$. Barium, lead, iron (III) oxide, and manganese dioxide were determined by Inductively Coupled Plasma Spectroscopy according to Environmental Protection Agency (US) methods 200.7 and 200.8 (http://www3.epa.gov).

\subsection{DNA extraction}

Total DNA was extracted from duplicate $0.5 \mathrm{~g}$ samples using the PowerSoil $^{\mathrm{TM}}$ DNA Isolation kit (Mo Bio Labs, Inc., Carlsbad, CA, USA) according to the manufacturer's instructions. The concentration and quality of extracted DNA were determined by a NanoDrop ND1000 spectrophotometer (Thermo Scientific, Wilmington, DE, USA).

\subsection{Amplification and sequencing of partial 16S rRNA genes}

Bacterial 16S rRNA genes were amplified and prepared for sequencing with the Illumina MiSeq system (Illumina Inc., San Diego, USA), according to the manufacturer's protocol. Primers $341 \mathrm{~F}$ and 785R, with added overhang adapters, were used for the primary amplification with the KAPA HiFi ${ }^{\text {TM }}$ Hotstart ReadyMix (KAPA Biosystems Inc., Wilmington, MA, USA). To minimize potential random PCR biases, each DNA preparation was amplified in triplicate. After indexing PCR, the amplicons were purified with Agencourt AMPure XP beads (Beckman Coulter, Brea, CA, USA), normalized, and pooled. The pooled sample was sequenced at the Barents Biocentre Lab, Troms $\varnothing$, Norway on an Illumina MiSeq platform, using a $2 \times 300$ bp paired end protocol.

The raw sequence data have been submitted to the EMBL database under the accession number ERP023770.

\subsection{Sequence analysis}

Sequence analyses were carried out using the Quantitative Insights Into Microbial Ecology (QIIME v.1.8) pipeline (Caporaso et al., 2010). The forward and reverse sequence reads were joined using the join_paired_end script (Erik Aronesty 2011; http://qiime.org/ scripts/join_paired_ends.html). Quality filtering was conducted by removal of barcodes, adapters and short and low quality sequences, as described by Bokulich et al. (2013). The qualified sequences were clustered into Operational Taxonomic Units (OTUs) based on 97\% sequence similarity by the open-reference OTU picking protocol. A representative sequence from each OTU was aligned to the GreenGenes (version May 2013) public database (http://greengenes.lbl.gov) using the PyNAST software (DeSantis et al., 2006). By this step, taxonomy assignment, sequence alignment, and phylogenetic tree-building were obtained. All OTUs observed just once in the community (i.e. singletons) and chloroplast-affiliated reads were removed before performing alpha and beta diversity analyses.

\subsection{Statistical analyses}

The Chao1 species richness and the community evenness $\left(\mathrm{H}^{\prime} / \mathrm{H}^{\prime}{ }_{\text {max }}\right.$, where $\mathrm{H}^{\prime}$ is the actual Shannon diversity index and $\mathrm{H}_{\text {max }}^{\prime}$ the Shannon index if all OTUs were equally represented) were estimated from each sample by the QIIME tool by averaging 100 resamplings of 4500 sequence reads (Chao, 1984; Shannon and Weaver, 1948). To test the null hypothesis that there were no differences in richness or evenness between different depth layers and different locations, a 2-way analyses of variance (ANOVA) with replicate (for distances 30, 50 and $210 \mathrm{~m}$ ) and without replicate (for distance of 100 and $150 \mathrm{~m}$ ) were performed. Community beta-diversities were calculated as Bray-Curtis similarities after Hellinger transformation of sequence read frequencies and multivariate ordination of the BrayCurtis distances was performed by principal coordinates analysis (PCoA) in R. The statistical significance of the PCoA ordination pattern was tested by the ANOSIM (analysis of similarity) method as implemented in the vegan package of R (Oksanen et al., 2012). To determine which taxa contributed the most to the differences between the sampling locations, the univariate ANOVA function mvabund in $\mathrm{R}$ (Wang et al., 2012), with adjusted p-values for multiple testing, was employed. The potential relationships between changes in community composition and environmental and geochemical variables were disentangled by distance-based redundancy analysis (db-RDA) based on the Bray-Curtis similarity matrix (Legendre and Anderson, 1999). The barium and nitrate data were log transformed prior to standardization of variables. Variation partitioning was employed to quantify the individual contributions by each explanatory parameter to explained bacterial beta-diversity and ANOVA tests on partial RDA ordinated data by 1000 Monte Carlo permutations were used to assess the significance of each effect. The statistical analyses were performed in the R (v.2.15.3) statistical packages (http://vegan.r-forge. r-project.org).

\section{Results and discussion}

\subsection{Sediment composition and deposition of drill cuttings}

According to inspection of the corer samples, the natural sediments at the Bønna area comprised a layer of brownish flocculent fine silt overlying more consolidated glacio-marine blue-gray clay, with small scattered dark-colored stones on the surface. The thickness of the upper layer varied from approximately two to four centimeters.

Visual inspection of the seafloor on-site using the ROV and recorded with both video and stills camera confirmed physical smothering of the native sediment by drill cuttings and some cement remains in the immediate vicinity of the drilling site, with a more widespread but less intense deposition farther from the drilling location. In a northern direction, the deposition was reduced to maximally two millimeters at a distance of $100 \mathrm{~m}$ and was not visible by $155 \mathrm{~m}$. A similar trend was evident in the easterly direction, where up to $30 \mathrm{~mm}$ deposition was seen at a distance of $30 \mathrm{~m}$, decreasing to $10-20 \mathrm{~mm}$ at $50 \mathrm{~m}$ and no visible deposition was observed by $210 \mathrm{~m}$ (Fig. 1). However, even within the radius of extensive drilling waste discharge, the deposition was patchy, as shaped by the undulating seafloor at this location.

Markedly elevated concentrations of barium in the uppermost one centimeter sediment layer were observed at $30 \mathrm{~m}$ and $50 \mathrm{~m}(11,000$ and $17,000 \mathrm{mg} \mathrm{kg}^{-1}$, respectively, relative to $\leq 700 \mathrm{mg} \mathrm{kg}^{-1}$ in the $210 \mathrm{~m}$ cores; (Fig. 2). However, even at the most distant sampling site, the post-drilling Ba concentration was more than doubled, as compared with the values found in a pre-drilling survey of 2010 

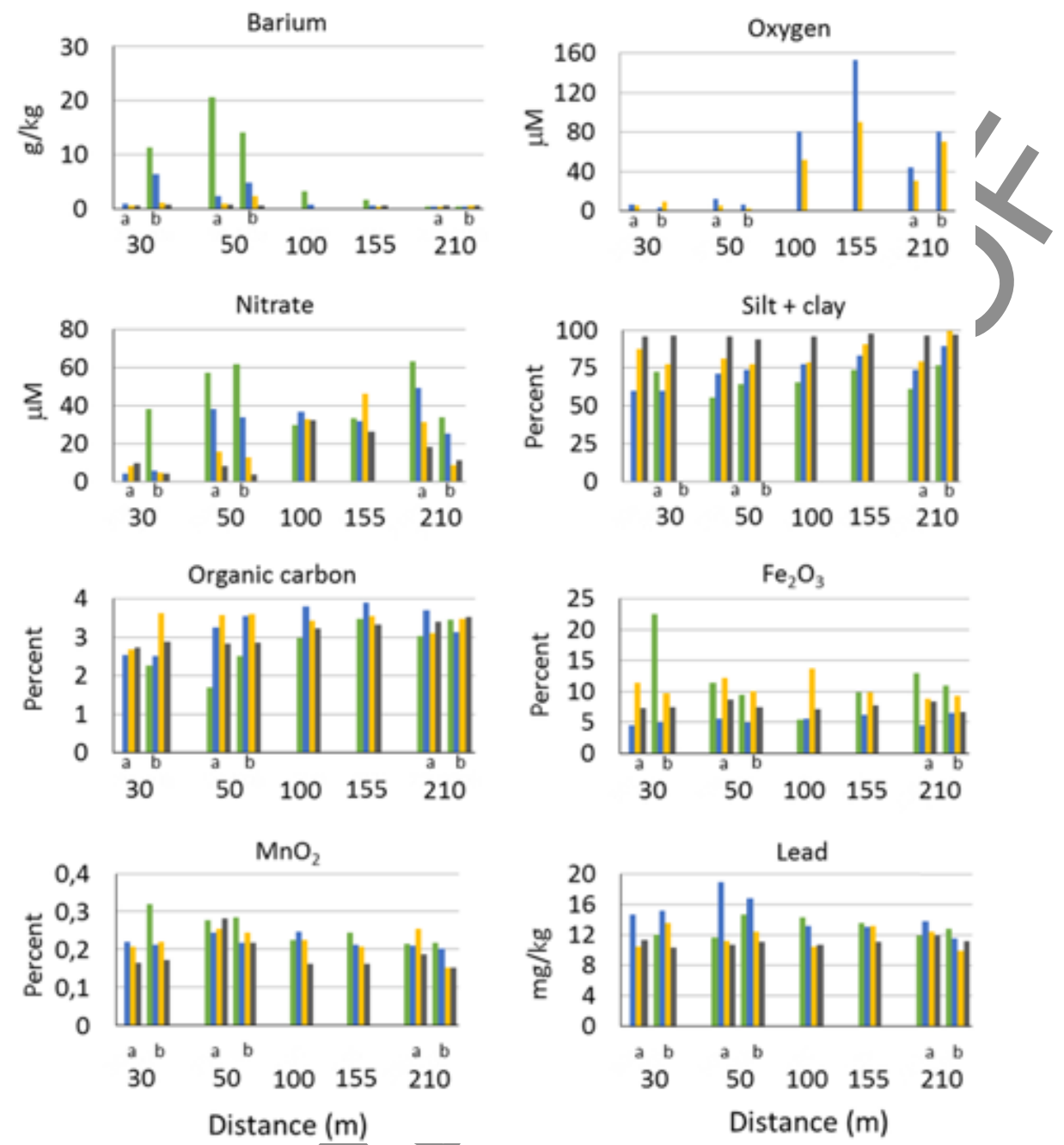

Fig. 2. Values of environmental variables recorded at different distances from the drilling site $(30,50$ and $210 \mathrm{~m}$ in duplicate $=\mathrm{a}$ and $\mathrm{b})$ and in different depth layers. Colors: 0-1 cm, green; 1-2 cm, blue; 2-5 cm, yellow; 5-10 cm, dark gray. Oxygen concentrations are only presented for the midpoints of the 1-2 and 2-5 cm layers. (For interpretation of the references to color in this figure legend, the reader is referred to the web version of this article.)

(Mannvik et al., 2011), indicating that discharged drilling mud, possibly released both directly to the seafloor and from the rig, had been spread thinly in a much wider radius than indicated by the visual deposition. Unexpectedly, the Ba levels from $1 \mathrm{~cm}$ below the surface (bsf) and downwards in one of the $30 \mathrm{~m}$ cores were close to the background level, indicating a distinct patchiness in residual barite even close to the drilling location

For the oxygen, just the concentrations within the intermediate sections of $1-2 \mathrm{~cm}$ and $2-5 \mathrm{~cm}$ bsf are presented in Fig. 2, as the onboard measurements by the needle electrode in the uppermost $0-1 \mathrm{~cm}$ layer proved highly unstable, while measurements below $5 \mathrm{~cm}$ bsf were impracticable for technical reasons. Significant oxygen concentrations were observed several centimeters into the sediment at the less affected sampling sites beyond $100 \mathrm{~m}$. The influx of biogenic sedimentary organic material at this continental margin location, with a water depth of approximately $1400 \mathrm{~m}$, should be expected moderate, resulting in a correspondingly low $\mathrm{O}_{2}$-consumption in the upper seafloor. The exceptionally low temperature of $-1{ }^{\circ} \mathrm{C}$ at the seafloor likely also contributed to low metabolic activity. Correspondingly deep oxygen penetration into sediment has been observed both at continental margin habitats (Cai and Sayles, 1996;
Boetius and Damm, 1998) and by measurements at adjacent Arctic Ocean and Barents Sea locations (Hulth et al., 1994). The oxygen penetration was reduced at the $30 \mathrm{~m}$ and $50 \mathrm{~m}$ sampling sites, as the $\mathrm{O}_{2}$ saturation there was $<5 \%$ already at $1.5 \mathrm{~cm}$ bsf while 13 to $37 \%$ saturation was maintained $3.5 \mathrm{~cm}$ bsf at the more distant cores. Low nitrate concentrations below $1 \mathrm{~cm}$ at the two nearest distances also pointed to a steeper shift towards anaerobicity close to the drilling sites. These data confirmed previous observations that discharge of water based drilling muds affects oxygen distribution in the sediment (Schaanning et al., 2008; Trannum et al., 2010; Bakke et al., 2013). The factors that may have contributed to reduced aerobicity are stimulated heterotrophic activity from organic ingredients in the drilling mud (Bakke et al., 2013), reduced oxygen influx due to capping by fines (drilling mud, finely crushed rock and cement) deposited onto the seabed or less bioturbation by burrowing animals. The spent material discharged to the seafloor next to the drilling site during the present operation was purely from the top sections of the drilling location where the drilling mud contained no organic ingredients, just bentonite (clay), soda ash and barite, with sea water as fluid. Hence, reduced oxygen penetration appears as a more plausible cause of the observed oxygen depletion than stimulation of het- 
erotrophic growth. The fact that the organic carbon concentrations in the samples most heavily marked by drilling mud discharge were lower than at the more remote sampling sites or in the deeper sections of the sediment (Fig. 2), pointed in the same direction. On the other hand, nor did the grain size analyses indicate significant spatially related differences in the top layer particle distribution. Rather, a consistent pattern of increased fineness with increasing sediment depth was observed, as $55-77 \%$ of the sediment were in the clay + silt category $(<63 \mu \mathrm{m}$ particle size $)$ in the $0-1 \mathrm{~cm}$ layer while this fraction constituted $94-98 \%$ in the $5-10 \mathrm{~cm}$ bsf sections of the cores (Fig. 2). The concentrations of lead varied within the range of 14.6-19.4 $\mathrm{mg} \mathrm{kg}^{-1}$ established by the pre-drilling baseline survey at the Bønna location (Mannvik et al., 2011), while the ferric and manganese oxides, which both may be involved in anaerobic energy metabolisms in marine sediments (Beal et al., 2009; Algora et al., 2015) did not show unambiguous variations related to distance from the drilling location or sediment depth.

\subsection{The unperturbed bacterial community}

A total of 494,017 high-quality 16S rRNA gene sequence tags, grouped into a total of 18,720 operational taxonomic units (excluding singleton OTUs) at 3\% dissimilarity level, were obtained from the 32 sediment samples (eight cores times four sections from each core). As the visual and chemical indices of disturbance of the native sediment by drilling waste discharge generally were confined to within $100 \mathrm{~m}$ from the drilling location, we anticipated the bacterial communities at the most distant, i.e. $210 \mathrm{~m}$, sites to be representative of the indigenous microbiota at this $1400 \mathrm{~m}$ depth continental margin location. The community data at this site confirmed the bacterial richness of marine sediments which previously has been demonstrated by various analytical approaches (Torsvik et al., 1998; Zinger et al., 2011; Nguyen and Landfald, 2015) as the Chao1 estimates of OTU richness were in the range 3000 to 5000 (Table 1). The taxonomic classification identified 37 groups at phylum-level separation, including 21 established phyla (Supplementary table \$1). Predominance by Proteobacteria, and the gamma class in particular, also appears as a universal characteristic of marine sediments (Schauer et al., 2010; Zinger et al., 2011; Bowen et al., 2012; Hamdan et al., 2013). In the $210 \mathrm{~m}$ samples, the Gammaproteobacteria made up $27.9 \%$ of sequence tags, with the metabolically versatile family Piscirickettsiaceae (Fryer and Lannan, 2007) as the main component ( $40.9 \%$ of gamma sequence tags). Other prominent groups of Gammaproteobacteria were the Chromatiales, Enterobacteriaceae and the HTCC2188 clade of oligotrophic marine bacteria (Cho and Giovannoni, 2004), which constituted $12.4 \%, 7.6 \%$ and $4.4 \%$, respectively, of gamma sequence tags. The Deltaproteobacteria $(15.3 \%$ of total tags) were strongly represented by the uncultivated deep-sea trench sediment group NB1-j (Yanagibayashi et al., 1999), as 43.5\% of the deltaproteobacterial sequence tags affiliated with this class. The nitrite-oxidizing genus Nitrospina (Lücker et al., 2013) was also abundant (21\%). Among the Alphaproteobacteria (13.4\% of total tags), the family Rhodospirillaceae constituted $40.0 \%$. Besides the Proteobacteria, the phyla Chloroftexi, Bacteroidetes (predominantly Cytophagales and Flavobacteriales), Acidobacteria and Planctomycetes each constituted from 5.7 to $6.4 \%$ of total sequence tags (Table S1).

In the $210 \mathrm{~m}$ cores the distribution between major phylogenetic groups showed moderate and inconsistent variations among samples from the different sediment depths. This indicated that the observed environmental changes down the upper $10 \mathrm{~cm}$ of sediment, although involving markedly reduced oxygen and nitrate levels (Fig. 2), still had too weak selective force to impose noticeable differences in bacterial community structure at this specific site.
Table 1

Sequencing outcome and diversity estimates based on partial 16S rRNA gene sequence data.

\begin{tabular}{|c|c|c|c|c|}
\hline Dist (m) & Layers $(\mathrm{cm})$ & No. reads ${ }^{\mathrm{a}}$ & Chao $^{\text {b }}$ & Even-ness $^{c}$ \\
\hline \multirow[t]{4}{*}{$30(1)$} & $0-1$ & 20839 & 3070 & 0.81 \\
\hline & $1-2$ & 10325 & & 0.89 \\
\hline & $2-5$ & 20764 & 4151 & 0.91 \\
\hline & 5-10 & 21580 & 2411 & 0.84 \\
\hline \multirow[t]{4}{*}{$30(2)$} & $0-1$ & 28869 & 3496 & 0.85 \\
\hline & $1-2$ & 35011 & 4215 & 0.85 \\
\hline & $2-5$ & 23574 & 4116 & 0.91 \\
\hline & 5-10 & 12489 & 2948 & 0.89 \\
\hline \multirow[t]{4}{*}{$50(1)$} & $0-1$ & 9480 & 3513 & 0.90 \\
\hline & $1-2$ & 5779 & 4264 & 0.92 \\
\hline & $2-5$ & 5690 & 3810 & 0.91 \\
\hline & 5-10 & & 3345 & 0.90 \\
\hline \multirow[t]{4}{*}{$50(2)$} & $0-1$ & 20540 & 2763 & 0.87 \\
\hline & $1-2$ & 32582 & 5433 & 0.93 \\
\hline & $2-5$ & 17844 & 3408 & 0.90 \\
\hline & & 20864 & 3248 & 0.85 \\
\hline \multirow[t]{4}{*}{100} & & 36862 & 4904 & 0.91 \\
\hline & & 5251 & 3401 & 0.89 \\
\hline & $2-5$ & 5307 & 2834 & 0.89 \\
\hline & 5-10 & 15842 & 2775 & 0.85 \\
\hline \multirow[t]{12}{*}{155} & & 5367 & 3145 & 0.91 \\
\hline & & 6432 & 3616 & 0.91 \\
\hline & $2-5$ & 22728 & 4105 & 0.90 \\
\hline & & 16476 & 2626 & 0.87 \\
\hline & & 6041 & 4194 & 0.93 \\
\hline & $1-2$ & 6272 & 3659 & 0.91 \\
\hline & $2-5$ & 13479 & 3676 & 0.90 \\
\hline & $5-10$ & 10087 & 3754 & 0.91 \\
\hline & $0-1$ & 23340 & 4930 & 0.92 \\
\hline & $1-2$ & 6982 & 3972 & 0.91 \\
\hline & $2-5$ & 13789 & 4575 & 0.91 \\
\hline & 5-10 & 7411 & 3346 & 0.91 \\
\hline
\end{tabular}

Quality-checked reads after pre-filtering and removal of singletons.

Computed by 100 times resampling of 4500 quality-checked sequence tags. Calculated with base 2 logarithms.

\subsection{Community effects of drilling waste discharge}

The partial 16S rRNA gene sequence data established that the drilling activity resulted in alterations of the bacterial communities in the uppermost sediment layers close to the drilling site. The 32 samples grouped with statistical significance (ANOSIM Rvalue $=0.71 ; \mathrm{p}=0.001$ ) into four PCoA-generated clusters, among which two were associated with the area visually affected by drilling waste discharge (Fig. 3). The samples from the uppermost two centimeters at $30 \mathrm{~m}$ distance constituted one cluster (group 1) and the $0-1 \mathrm{~cm}$ layer at $50 \mathrm{~m}$ a second cluster (group 2). All intermediate depth $(2-5 \mathrm{~cm})$ and more distant upper layer $(100-210 \mathrm{~m})$ sequences made up group 3 while group 4 included the deepest, 5-10 cm communities from all cores. The overlap between the latter two clusters was associated with the deep samples from the $210 \mathrm{~m}$ site, which, as mentioned, showed less community structure variation between different strata than the remaining sampling sites.

The community distinctiveness of the upper layers close to the drilling site was not associated with reduced OTU richness, while the upper $2 \mathrm{~cm}$ of the $30 \mathrm{~m}$ cores showed a minor reduction in average community evenness, i.e. $0.85 \pm 0.03$, as compared with $0.91 \pm 0.01$ for the remaining sampling sites $(\mathrm{p}=0.02$ by Student $t$-test). This indicated a slight shift towards stronger numerical dominance by high-abundance phylogenetic groups at this most affected location (Table 1). We conclude that the overall bacterial diversity at the seafloor proved robust against the kind of environmental insult ex- 


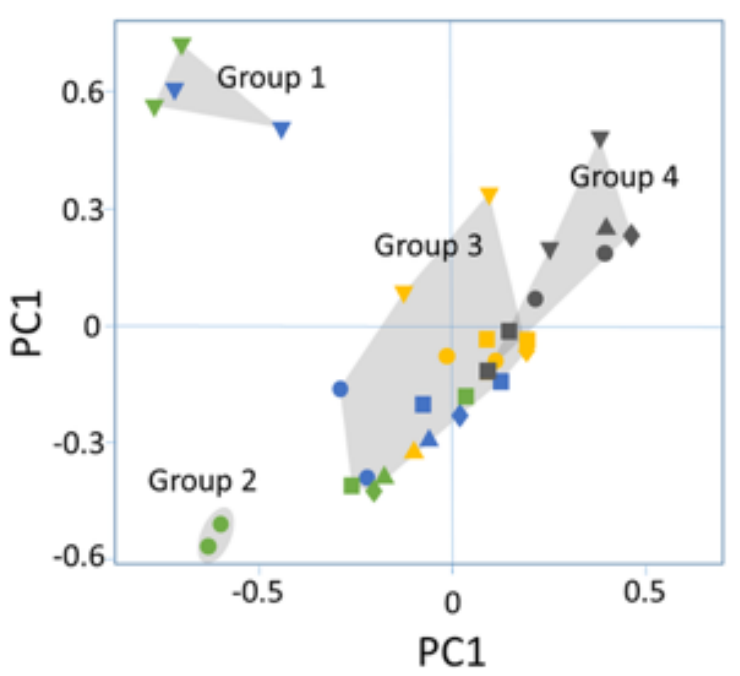

Fig. 3. Principal coordinates analysis of complete OTU data. Icons separate different distances from drilling site: triangles pointing down, $30 \mathrm{~m}$; circles, $50 \mathrm{~m}$; diamonds, $100 \mathrm{~m}$; triangles pointing up, $155 \mathrm{~m}$; squares, $210 \mathrm{~m}$. Colors: $0-1 \mathrm{~cm}$, green; $1-2 \mathrm{~cm}$, blue; $2-5 \mathrm{~cm}$, yellow; $5-10 \mathrm{~cm}$, dark gray. (For interpretation of the references to color in this figure legend, the reader is referred to the web version of this article.)

erted by the drilling waste discharge. The recurring pattern in the sampled material was a minor reduction in diversity down the sediment, as the average richness and evenness values were significantly lower in the $5-10 \mathrm{~cm}$ bsf layers than in the $0-5 \mathrm{~cm}$ layers $(\mathrm{p}<0.05$ by Student $t$-test, based on weighted average values for the $0-5 \mathrm{~cm}$ samples).

A principal components ordination after assembling the OTUs into the taxonomic ranks of class or order confirmed the clustering pattern of Fig. 3 (data not shown) and subsequent univariate ANOVA analysis disentangled the phylogenetic groups that contributed significantly to this patterning. The 11 most abundant ( $\geq 1 \%$ of sequence tags in at least one sample) of these groups are presented in Fig. 4. The defining feature of the top two centimeters of sediment at $30 \mathrm{~m}$ distance from the drilling site, corresponding to group 1 in Fig. 3 , was a unique presence of representatives of the class Mollicutes and orders Desulfuromonadales (mainly family Desulfuromonadaceae) and Clostridiales. On average, the three taxa constituted $5.7 \%, 3.8 \%$ and $2.7 \%$, respectively, of total sequence tags in these sediment sections (Fig. 4). The same sediment samples also harbored particularly high fractions of the orders Flavobacteriales and Alteromonadales. Opposite to the mentioned taxa, the remaining seven influential groups principally showed a depth-related variation by being more confined

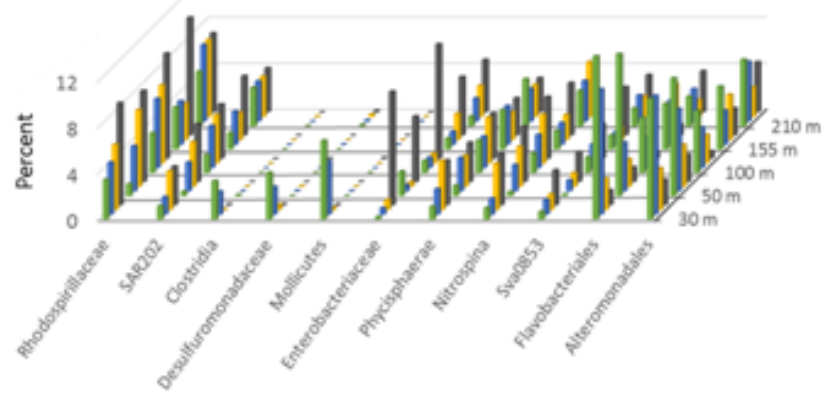

Fig. 4. Distribution among samples of phylogenetic groups giving significant contributions to explained community variations. Colors: $0-1 \mathrm{~cm}$, green; $1-2 \mathrm{~cm}$, blue; 2-5 cm, yellow; 5-10 cm, dark gray. (For interpretation of the references to color in this figure legend, the reader is referred to the web version of this article.) to the deeper sections of the sediment cores. The high presence of Enterobacteriales (family Enterobacteriaceae) constituted a particularly distinguishing feature of the deepest, $5-10 \mathrm{~cm}$ half of the cores. This group, of which $91 \%$ belonged to a single operational taxonomic unit, ranged from 4.5 to $9.9 \%$ of total sequence tags in these sections, while being distinctly less prominent in the overlaying strata.

Variation partitioning of dbRDA ordinated data was used to shed light on the contributions by the recorded environmental factors to observed community variations (Table 2). The analysis attributed $25.4 \%$ of the overall variation to the impact of the included constrained variables $(P=0.001)$. The individual contributions were rather similar by varying from 3.0 to $4.5 \%$ and those of barium, $\%$ (silt + clay) and nitrate showed significance by permutation tests ( $p \leq 0.05$ ). Due to low solubility product of barite and the relatively high concentration of sulfate in seawater, the saturation concentration of $\mathrm{Ba}^{2}+$ is estimated at less than $50 \mu \mathrm{g}$ per liter (Neff, 2008). As Sivolodskii (2012) finds minimum inhibitory concentrations of $\mathrm{Ba}^{2}+$ towards a number of gram negative bacteria in the range 0.5-50 g per liter, the barium load, as such, appeared as an unlikely cause of the observed community changes near the drilling site. Rather, the residual barium principally served as an indicator of the extent of residual drilling mud, and the bacterial community structuring effect of the mud deposition was plausibly a result of other factors. The grain size principally varied in accordance with sediment depth, not by distance from the drilling location, implying that the observed relationship between this factor and community composition reflected the distinctiveness of the deep communities rather than being a consequence of the drilling waste discharge.

Relationships between oxygen regime and bacterial community structure under otherwise similar environmental conditions have been demonstrated in experimental sediment setups (Vitte et al., 2013; Militon et al., 2015), implying that the observed increase in anaerobicity near the drilling site contributed to the observed restructuring of the upper sediment bacterial communities. The emergence of significant fractions of both fermentative Clostridiales and anaerobically respiring Desulfuromonadales in the upper $2 \mathrm{~cm}$ at $30 \mathrm{~m}$ distance indicated establishment of some form of syntrophic relationship involving these groups as a consequence of the sediment perturbation. Our data gave no clue to what sediment components might be involved, neither as carbon source nor as electron acceptor. The Desulfuromonadales, mainly including Desulfuromonadaceae in the present material (Supplementary table S1), are associated with dissimilative reduction of elemental sulfur, $\mathrm{Fe}^{3+}$ and $\mathrm{Mn}^{4+}$ (Kuyver et al., 2005). However, no consumption of e.g. ferric oxide through a respiratory process could be disclosed in a high and variable background concentration in the sediment. The unique appearance of representatives of the wall-less and anticipated parasitic Mollicutes in the top layers at $30 \mathrm{~m}$ remained without support in environmental data. It indicated that the environmental change exerted by the mud discharge had stimulated the colonization by some otherwise rare, microbial eukaryotic host or, alternatively, a proliferation of the Mollicutes parasites within an existing population of prospective hosts.

Table 2

Partitioning of contributions to explained community variation by environmental factors. Significant contributions $(\mathrm{P}<0.01)$ are shown in bold.

\begin{tabular}{lll}
\hline Parameters & Variation (\%) & P value \\
\hline Nitrate & 4.5 & $\mathbf{0 . 0 1}$ \\
\% silt + clay & 4.2 & $\mathbf{0 . 0 1}$ \\
Barium & 3.7 & $\mathbf{0 . 0 4}$ \\
$\mathrm{TOC}$ & 3.6 & 0.06 \\
$\mathrm{Fe}_{2} \mathrm{O}_{3}$ & 3.2 & 0.24 \\
$\mathrm{MnO}_{2}$ & 3.2 & 0.24 \\
$\mathrm{~Pb}$ & 3.0 & 0.34 \\
\hline
\end{tabular}


However, the current literature does not give convincing clues to the habitats of marine Mollicutes.

The unique presence of the Clostridiales, Desulfuromonadales and Mollicutes in the uppermost centimeters at $30 \mathrm{~m}$ distance from the drilling location pointed to one or more of these taxa as prospective candidates as microbial bioindicators of seafloor perturbation by drilling waste. Preceding studies have linked Clostridiales and Mollicutes to bacterial community change after oil contamination in marine environments and even indicated the Clostridiales as a possible bioindicator of such contamination (dos Santos et al., 2011; Hasegawa et al., 2014; Koo et al., 2014). As hydrocarbons or other organic constituents were not discharged with the present drilling waste, it seems that enhanced anaerobicity, as such, or some other environmental change not revealed by the present study, triggered a similar community response as the oil contamination.

The present study is, to our knowledge, the first to address the microbial effects of drilling waste discharge on the seafloor by a whole-community analysis approach. While the expected community-structuring influences of oil-based muds may draw heavily on the insights obtained from the broad research on hydrocarbon contamination in marine environments in general (Röling et al., 2004; Head et al., 2006; Liu and Liu, 2013; Stauffert et al., 2013; Kimes et al., 2014), the effects of water-based drilling mud discharges are without obvious parallels in other kinds of perturbation of marine microbial habitats. The present study addressed such community changes in the immediate aftermath of a drilling waste discharge, and we identified phylogenetic groups of bacteria that appeared exclusively associated with the immediate surroundings of the drilling site, i.e. the area most heavily affected by drill cuttings discharge. However, comparative studies from additional drilling sites are needed to confirm if the unexpected emergence of Mollicutes and Clostridiales represents a general phenomenon, thereby making these groups prospective candidates as supplementary biological indicators to the macrofauna in locations exposed to offshore drilling activity.

\section{Acknowledgements}

This work was supported by Eni Norge AS through the BARCUT project. We thank the captain and crew of M/V Njord Viking (Viking Supply Ships, Gothenburg) and the Oceaneering ROV crew for their compliance and efforts during the sampling cruise. Thanks to John Eirik Paulsen for his valuable comments on the manuscript. Thanks also to Ida Maylen Øverleir for assistance with sample collection and preliminary analyses and Seila Pandur for assistance with the Illumina sequencing.

\section{Appendix A. Supplementary data}

Supplementary data to this article can be found online at https:// doi.org/10.1016/j.marpolbul.2017.10.039.

\section{References}

Algora, C., Vasileiadis, S., Wasmund, K., Trevisan, M., Krüger, M., Puglisi, E., Adrian, L., 2015. Manganese and iron as structuring parameters of microbial communities in Arctic marine sediments from the Baffin Bay. FEMS Microbiol. Ecol. 91, (fiv056).

Artz, R.R.E., Semple, K.T., Killham, K., Prosser, J.I., Paton, G.I., 2002. The potential for anaerobic mineralisation of hydrocarbon constituents of oily drill cuttings from the North Sea seabed. J. Environ. Monit. 4, 553-557.

Bakke, T., Klungsøyr, J., Sanni, S., 2013. Environmental impacts of produced water and drilling waste discharges from the Norwegian offshore petroleum industry. Mar. Environ. Res. 92, 154-169.

Beal, E.J., House, C.H., Orphan, V.J., 2009. Manganese- and iron-dependent marine methane oxidation. Science $325,184-187$.

Bertics, V.J., Ziebis, W., 2009. Biodiversity of benthic microbial communities in bioturbated coastal sediments is controlled by geochemical microniches. ISME J. 3, 1269-1285.
Bienhold, C., Boetius, A., Ramette, A., 2012. The energy-diversity relationship of complex bacterial communities in Arctic deep-sea sediments. ISME J. 6, 724-732. Boetius, A., Damm, E., 1998. Benthic oxygen uptake, hydrolytic potentials and microbial biomass at the Arctic continental slope. Deep-Sea Res. I 45, 239-275.
chentic

Bokulich, N.A., Subramanian, S., Faith, J.J., Gevers, D., Gordon, J.I., Knight, R., Mills, D.A., Caporaso, J.G., 2013. Quality-filtering vastly improves diversity estimates from Illumina amplicon sequencing. Nat. Methods 10, 57-59.

Bowen, J.L., Morrison, H.G., Hobbie, J.E., Sogin, ML., 2012. Salt marsh sediment diversity: a test of the variability of the rare biosphere among environmental replicates. ISME J. 6, 2014-2023.

Cai, W.J., Sayles, F.L., 1996. Oxygen penetration depths and fluxes in marine sediments. Mar. Chem. 52, 123-131.

Caporaso, J.G., Kuczynski, J., Stombaugh, J., Bittinger, K., Bushman, F.D., Costello, E.K., Fierer, N., Pena, A.G., Goodrich, J.K., Gordon, J.I., Huttley, G.A., Kelley, S.T., Knights, D., Koenig, J.E., Ley, R.E., Lozupone, C.A., McDonald, D., Muegge, B.D., Pirrung, M., Reeder, J., Sevinsky, J.R., Turnbaugh, P.J., Walters, W.A., Widmann, J., Yatsunenko, T., Zaneveld, J., Knight, R., 2010. QIIME allows
analysis of high-throughput community sequencing data. Nat. Methods 7, analysis of high-throughput 335-336.

Chao, A., 1984. Non-parametric estimation of the number of classes in a population.

Scand. J. Stat. 11, 265-270.
Cho, J.C., Giovannoni, S.J., 2004. Cultivation and growth characteristics of a diverse group of oligotrophic marine Gammaproteobacteria. Appl. Environ. Microbiol. 70, 432-440.

Daan, R., Mulder, M., Witbaard, R., 2006. Oil contaminated sediments in the North Sea: environmental effects 20 years after discharges of OBM drill cuttings. In: NIOZ-Rapport 2006-4. Royal Netherlands Institute for Sea Research.

DeSantis, T.Z., Hugenholtz, P., Larsen, N., Rojas, M., Brodie, E.L., Keller, K., Huber, T., Dalevi, D., Hu, P., Andersen, G.L., 2006. Greengenes, a chimera-checked 16S rRNA gene database and workbench compatible with ARB. Appl. Environ. Microbiol. 72, 5069-5072.

dos Santos, H.F., Cury, J.C., do Carmo, F.L., dos Santos, A.L., Tiedje, J., van Elsas, Santos, H.F., Cury, J.C., do Carmo, F.L., dos Santos, A.L., Tiedje, J., van Elsas,
J.D., Rosado, A.S., Peixoto, R.S., 2011. Mangrove bacterial diversity and the impact of oil contamination revealed by pyrosequencing: bacterial proxies for oil pollution. PLoS One e16943, 6.

Dow, F.K., Davies, J.M., Raffaelli, D., 1990. The effects of drill cuttings on a model marine sediment system. Mar. Environ. Res. 29, 103-134.

Ellis, J.I., Fraser, G., Russell, J., 2012. Discharged drilling waste from oil and gas platforms and its effects on benthic communities. Mar. Ecol. Prog. Ser. 456, 5-302.

Fryer, J.L., Lannan, C.N., 2007. Piscirickettsiaceae fam. nov. In: Brenner, D.J., Krieg, N.R., Staley, J.T., Garrity, G.M. (Eds.), Bergey's Manual of Systematic Bacteriology, 2nd ed., Vol. 2, Springer-Verlag US, New York, p. 180.

Gates, A.R., Jones, D.O., 2012. Recovery of benthic megafauna from anthropogenic disturbance at a hydrocarbon drilling well (380 m depth in the Norwegian Sea). PLoS One 7, e44114.

PLoS One 7, e44114. 2013. Ocean currents shape the microbiome of Arctic marine sediments. ISME J.
(1), Gillevet, P.M., 7, 685-696.

Hasegawa, R., Toyama, K., Miyanaga, K., Tanji, Y., 2014. Identification of crude-oil components and microorganisms that cause souring under anaerobic conditions. Appl. Microbiol. Biotechnol. 98, 1853-1861.

Head, I.M., Jones, D.M., Röling, W.F.M., 2006. Marine microorganisms make a meal of oil. Nat. Rev. Microbiol. 4, 173-182.

Hulth, S., Blackburn, T.H., Hall, P.O.J., 1994. Arctic sediments (Svalbard): consumption and microdistribution of oxygen. Mar. Chem. 46, 293-316.

Jones, D.O.B., Gates, A.R., Lausen, B., 2012. Recovery of deep-water megafaunal assemblages from hydrocarbon drilling disturbance in the Faroe-Shetland Channel. semblages from hydrocarbon drilling
Mar. Ecol. Prog. Ser. 461, 71-82.

Kennicutt, M.C., Keeney-Kennicutt, W.L., Bresley, B.J., Fenner, F., 1983. The use of pyrolysis and barium distributions to assess the areal extent of drilling fluids in surficial marine sediments. Environ. Geol. 4, 239-249.

Kimes, N.E., Callaghan, A.V., Suflita, J.M., Morris, P.J., 2014. Microbial transformation of the deepwater horizon oil spill - past, present, and future perspectives. Front. Microbiol. 5, 603.

Koo, H., Mojib, N., Thacker, R.W., Bej, A.K., 2014. Comparative analysis of bacterial community metagenomics in coastal Gulf of Mexico sediment microcosms following exposure to Macondo oil (MC252). Antonie Van Leeuwenhoek 106, 993-1009.

Kuyver, J., Rainey, F.A., Widdel, F., 2005. Desulfuromonadaceae fam. nov. In: Brenner, D.J., Krieg, N.R., Staley, J.T., Garrity, G.M. (Eds.), Bergey's Manual of Systematic Bacteriology, 2nd. ed., vol. 2 The Proteobacteria, Part C. Springer New tematic Bacterio

Legendre, P., Anderson, M.J., 1999. Distance-based redundancy analysis: testing multispecies responses in multifactorial ecological experiments. Ecol. Monogr. $69,1-24$.

Liu, Z.F., Liu, J.Q., 2013. Evaluating bacterial community structures in oil collected from the sea surface and sediment in the northern Gulf of Mexico after the Deepwater horizon oil spill. Microbiology 2, 492-502.

Lücker, S., Nowka, B., Rattei, T., Spieck, E., Daims, H., 2013. The genome of Nitrospina gracilis illuminates the metabolism and evolution of the major marine nitrite oxidizer. Front. Microbiol. 4, 27.

Mannvik, H.P., Wassbotn, I.H., Cochrane, S.K.J., 2011. Environmental survey in region IX and X, Barents Sea, 2010. In: Akvaplan-niva Report. pp. 5000-5003.

Militon, C., Jezequel, R., Gilbert, F., Corsellis, Y., Sylvi, L., Cravo-Laureau, C., Duran, R., Cuny, P., 2015. Dynamics of bacterial assemblages and removal of polycyclic R., Cuny, P., 2015. Dynamics of bacterial assemblages and removal of polycyclic
aromatic hydrocarbons in oil-contaminated coastal marine sediments subjected aromatic hydrocarbons in oil-contaminated coastal marine sediments subject
to contrasted oxygen regimes. Environ. Sci. Pollut. Res. 22, 15260-15272.

Neff, J.M., 2008. Estimation of bioavailability of metals from drilling mud barite. Integr. Environ. Assess. Manag. 4, 184-193. 
Nguyen, T.T., Landfald, B., 2015. Polar front associated variation in prokaryotic community structure in Arctic shelf seafloor. Front. Microbiol. 6, 17.

Oksanen, J.F., Blanchet, F.G., Kindt, R., Legendre, P., Minchin, P.R., O'Hara, R.B., et al., 2012. Package 'vegan' in. In: http://cran.r-project.org/.

Orcutt, B.N., Sylvan, J.B., Knab, N.J., Edwards, K.J., 2011. Microbial ecology of the dark ocean above, at, and below the seafloor. Mol. Biol. Rev. 75, 361-422.

Paulsen, J.E., Cochrane, S.K.J., Leikvin, O., Hansen, J., Torbergsen, H.E., Pierfelici, S., 2014. Assessing exploratory drilling impacts on an Arctic deepwater sea-pen habitat offshore Norway. In: Report SPE 168343. Society of Petroleum Engineers, (14 pp).

Phillips, C., Evans, J., Hom, W., Clayton, J., 1998. Long-term changes in sediment barium inventories associated with drilling-related discharges in the Santa Maria Basin, California, USA. Environ. Toxicol. Chem. 17, 1653-1661.

Roesch, L.F., Fulthorpe, R.R., Riva, A., Casella, G., Hadwin, A.K.M., Kent, A.D. Daroub, S.H., Camargo, F.A.O., Farmerie, W.G., Triplett, E.W., 2007. PyroseDaroub, S.H., Camargo, F.A.O., Farmerie, W.G., Triplett, E.W., 2007. Pyrose-

Röling, W.F.M., Milner, M.G., Jones, D.M., Fratepietro, F., Swannell, R.P.J., Daniel, F., Head, I.M., 2004. Bacterial community dynamics and hydrocarbon degradation during a field-scale evaluation of bioremediation on a mudflat beach contaminated with buried oil. Appl. Environ. Microbiol. 70, 2603-2613.

Sanders, P.F., Tibbetts, P.J.C., 1987. Effects of discarded drill muds on microbial populations. Philos. Trans. R. Soc. Lond. B Biol. Sci. 316, 567-585.

Schaanning, M.T., Trannum, H.C., Øxnevad, S., Carroll, J., Bakke, T., 2008. Effects of drill cuttings on biogeochemical fluxes and macrobenthos of marine sediments. J. Exp. Mar. Biol. Ecol. 361, 49-57.

Schauer, R., Bienhold, C., Ramette, A., Harder, J., 2010. Bacterial diversity and biogeography in deep-sea surface sediments of the South Atlantic Ocean. ISME J. 4, 159-170.

Shannon, C.E., Weaver, W., 1948. A mathematical theory of communication. Bell Syst. Tech. J. 27, 379-423-623-656.

Sivolodskii, E.P., 2012. Determination of the sensitivity of bacteria to barium ions, a taxonomic marker of the genus Pseudomonas. Microbiology 81, 112-117.

Stauffert, M., Cravo-Laureau, C., Jezequel, R., Barantal, S., Cuny, P., Gilbert, F., Cagnon, C., Militon, C., Amouroux, D., Mahdaoui, F., Bouyssiere, B., Stora, G.,
Merlin, F.X., Duran, R., 2013. Impact of oil on bacterial community structure in bioturbated sediments. PLoS One 8, e65347.

Torsvik, V., Daae, F.L., Sandaa, R.A., Øvreås, L., 1998. Novel techniques for analysing microbial diversity in natural and perturbed environments. J. Biotechnol. 64, 53-62.

Trannum, H.C., Nilsson, H.C., Schaanning, M.T., Øxnevad, S., 2010. Effects of sedimentation from water-based drill cuttings and natural sediment on benthic macrofaunal community structure and ecosystem processes. J. Exp. Mar. Biol. Ecol. 383, 111-121.

Trannum, H.C., Setvik, A., Norling, K., Nilsson, H.C., 2011. Rapid macrofaunal colonization of water-based drill cuttings on different sediments. Mar. Pollut. Bull. 62, 2145-2156.

Vitte, I., Duran, R., Hernandez-Raquet, G., Mounier, J., Jezequel, R., Bellet, V., Balaguer, P., Caumette, P., Cravo-Laureau, C.. 2013. Dynamics of metabolically active bacterial communities involved in PAH and toxicity elimination from oilcontaminated sludge during anoxic/oxic oscillations. Appl. Microbiol. Biotechcontaminated sludg

Wang, Q.R., Li, Y.C., Wang, Y., 2011. Optimizing the weight loss-on-ignition methodology to quantify organic and carbonate carbon of sediments from diverse sources. Environ. Monit. Assess. 174, 241-257.

Wang, Y., Naumann, U., Wright, S.T., Warton, D.I., 2012. mvabund- an R package for model-based analysis of multivariate abundance data. Methods Ecol. Evol. 3 , 471-474.

Wentworth, C.K., 1922. A scale of grade and class terms for clastic sediments. J. Geol. 30, 377-392.

Yanagibayashi, M., Nogi, Y., Li, L., Kato, C., 1999. Changes in the microbial community in Japan Trench sediment from a depth of $6292 \mathrm{~m}$ during cultivation without decompression. FEMIS Microbiol. Lett. 170, 271-279.

Zinger, L., Amaral-Zettler, L.A., Fuhrman, J.A., Horner-Devine, M.C., Huse, S.M., Welch, D.B., Martiny, J.B., Sogin, M., Boetius, A., Ramette, A., 2011. Global patterns of bacterial beta-diversity in seafloor and seawater ecosystems. PLoS One 6 , e2457

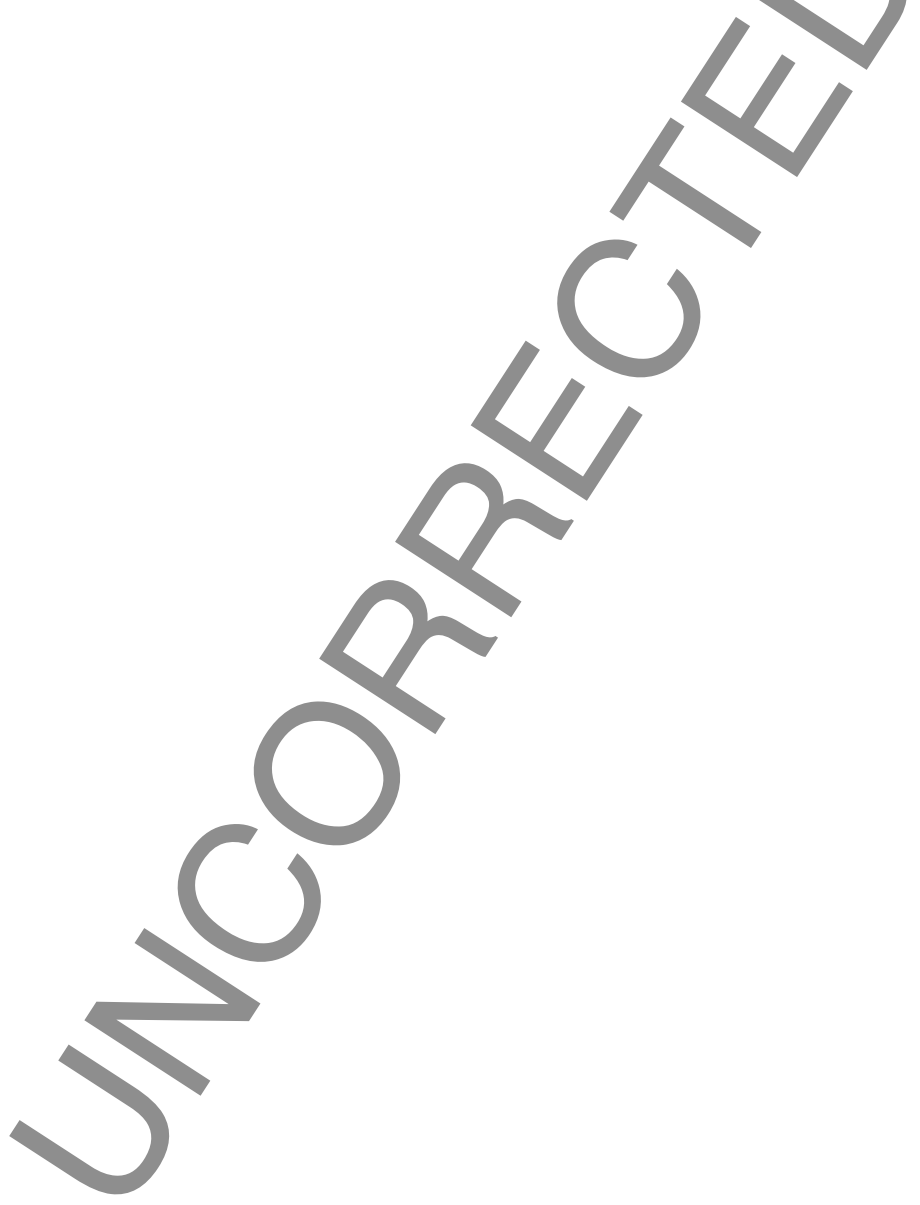

